\title{
Iranian EFL Learners' Preferences toward Classroom Oral Error Correction: With a Main Focus on Their Proficiency Level
}

\author{
Rana Kazemi \\ Department of English Language Teaching, Islamic Azad University-Ahar Branch, Ahar, Iran \\ Seyed Mahdi Araghi \\ Department of English Language Teaching, Payame Noor University, PO BOX 19395-3697, Tehran, Iran \\ Haniyeh Davatgari \\ Department of English Language Teaching, Islamic Azad University-Ahar Branch, Ahar, Iran
}

\begin{abstract}
There are many problems associated with oral error correction in the EFL classrooms. One of these common problems is the student and teacher disagreement on the amount of error correction, type, and techniques of correcting errors. This study based on the findings of a questionnaire administrated to 90 female EFL students in Pardisan Language Institute investigates: 1) Whether or not learners' (with different proficiency levels) prefer classroom oral error correction; 2) learners' prefer which types of oral error correction; and 3) Which techniques of correcting oral errors do the learners prefer. The findings of this study manifest that the majority of the students in three different levels (elementary, intermediate, and advanced) had strongly preferred that their oral errors should be corrected and they preferred to receive constant error correction. Also the majority of the students preferred vocabulary error correction over the other types of errors. Also the least favored oral error correction technique was the technique in which the teacher ignores the students' errors as for as the most favored techniques by students of three different levels were the ones in which teacher repeats the original question, asks students to repeat the utterance, explain why the response is incorrect, and finally the teacher gives students a hint which might enable them to notice the error and self-correct.
\end{abstract}

Index Terms - error, mistake, error correction, learner preferences

\section{INTRODUCTION}

Various factors influence student's success in foreign language (FL) learning. Top among these is the guidance, teachers provide while correcting student's oral errors. For this reason the teachers need to know learners' beliefs about language teaching and learning because a mismatch between students' expectations and the realities they encounter in the classroom can prevent improvement in the language acquisition (Horwitz, 1988). Nunan (1987) beliefs that one of the most serious blocks to learning is the mismatch between teacher and learner expectations about what should happen in the classroom. Moreover, concerning the preferences of Iranian EFL learners' at different proficiency levels there is still a need for determining which error correction techniques are the most successful at dealing with learners' errors. To sum up, this paper, deeply focusing on oral error correction among Iranian EFL learners' may provide appropriate answers to many of the English teachers' questions about how to deal and correct students oral errors in the classrooms.

\section{LITERATURE REVIEW}

Researches have investigated teachers' and students' perceptions of error correction and found mismatches between them. For example, Schulz's $(1996,2001)$ studies revealed that students' attitudes and preferences toward grammar instruction and error correction were more favorable than their teachers' preferences; that is, learners want more error correction. Katayama (2007) investigated Japanese students' preferences toward classroom oral error correction. The results indicated that students preferred teacher correction and having their 'pragmatic errors' corrected over the other types of errors. Yet, one would readily admit that it is important for learners to feel that their perceived needs are being catered to if they are to develop a positive attitude toward what they are learning.

\section{RESEARCH QUESTIONS AND HYPOTHESIS}

This study sought to find out answers to the following research questions:

1. Whether or not the Iranian EFL learners' at different proficiency levels prefer classroom oral error correction?

2. Learners prefer which types of oral error correction? (e.g. pronunciation and grammar)

3. Which techniques of correcting oral errors do the learners' prefer? 
Accordingly, the following hypotheses were formulated:

1. There is a positive preference among Iranian EFL learner's with different proficiency levels regarding oral error correction.

2. There is a positive preference in pronunciation correction among Iranian EFL learners.

3. Learners prefer self-correction over other correction techniques.

\section{Methodology}

\section{Participants}

90 female students enrolled at Pardisan English language institution participated in this study. The student participant's proficiency levels varied from elementary to advance. These participants were chosen among 150 female students by the institution's placement tests which is approved to be a standard test between all language institutions which teach new Interchange books, including reading, grammar, and oral interview components. The testers were MA or PHD professors whom taught English at universities and institutions. The total number of 150 population were divided into three groups of 50 elementary, 50 intermediate, and 50 advanced level students after the placement tests. Among 50 elementary students, 30 students with the closest scores were chosen. Similarly among 50 intermediate students, 30 students with the closest scores were chosen, and likewise 30 students from 50 advanced students with the closest scores were chosen and participated in the survey. Consequently, all the classes in three different levels were homogeneous. These 90 female students were divided into 6 classes: (2 elementary, 2 intermediate, and 2 advanced level classes).All student participants were EFL learners with nearly the same background knowledge and their ages ranged from 14 to 36 years old.

\section{Instruments}

A questionnaire (shown in the Appendix) was developed based on a literature review of previous studies of learner errors and teacher feedback on errors (Katayama, 2007) in order to elicit information on student's preferences regarding oral error correction. For student's better understanding the original questionnaire in English was translated into Persian. The Persian version of the questionnaire was checked out by three PHD professors to remove any suspicion on the translation matter. The questionnaire contains four sections. The first section contained questions eliciting demographic information, including the student's age, level of study, if ever they have lived in an English speaking country before, whether they speak English outside the classroom context or not?, and if they wish to improve their learning skills? The second section addressed Research Question 1 and asked the student's general opinions about the correction of oral errors in the classroom. The section contained four statements illustrating certain views that have been controversial among language researchers and educators for decades. These views included: whether or not learner errors should be corrected; when learner errors should be corrected (i.e., constantly or selectively); and who should correct errors, teachers or peers. The students were asked to indicate their degree of agreement or disagreement with four different statements. Response options were coded to 5-point scales, with 1 representing strongly disagree and 5 representing strongly agree. The students were given the option of explaining the reasons for their rating in order to provide this research with "useful" qualitative data. The third section addressed Research Question2 and asked about student's preferences for classroom error correction of different aspects of the language. The students were asked how often they wanted classroom error correction of different types of grammar; vocabulary, pragmatics, and discourse were used in the questionnaire. Participants rated each time on 5-point scale, with 1 representing never and 5 representing always with respect to frequency of correction. The last section addressed Research Question3 and asked about student's preferences for particular types of error correction techniques. The students were asked to rate ten different techniques of error correction (shown in section D of the questionnaire in the Appendix) provided by teachers, first as feedback to student's grammatical errors, and then as feedback to student's pronunciation errors for each technique. Examples of errors were presented in the questionnaire. The rating for student's opinions about each technique was measured on a 5-point scale, ranging from 1 representing bad to 5 representing very good(katayama,2007).

\section{Procedure}

For the main study, a total number of 90 female students were chosen among 150 female students from Pardisan English language institution. They were divided into 6 classes of elementary, intermediate and advanced levels by standard placement tests. The researcher was the teacher of those 6 classes for about a semester and during this period the student's oral errors were corrected by the 10 different techniques stated in the questionnaire. In order to ensure that the questionnaire was reliable and did not have any parts causing misunderstanding a pilot study was conducted with 50 students out of the same 90 students (8 elementary, 24 intermediate, and 18 advanced students) which were chosen randomly. After conducting the piloting of the questionnaire, Cronbach Alpha value was calculated for the different sections of the questionnaire. The Cronbachs' Alpha value calculated for each section items are as follows:

Section (B): $\alpha=0.53$

Section (Da): $\alpha=0.77$

Section (Db): $\alpha=0.8$

(ten rated feedbacks to student's grammatical errors).

(ten rated feedbacks to student's phonological errors).

The overall estimated $\alpha$ for the whole questionnaire was $0 / 88$ which indicated that the questionnaire was reliable. Having piloted the instrument, the researcher conducted the main course of the study. At the end of semester the total 
number of 90 students were gathered and supplied with the questionnaire. After that the sheets were scored according to the rating of the students and for the final result were analyzed by SPSS software.

\section{Data Analysis}

The data reported were analyzed by using descriptive statistical techniques by SPSS software including percentages and frequencies. The calculations of frequencies and percentages provided the findings about whether or not the Iranian EFL learners' prefer classroom oral error correction based on their level of proficiency.

\section{RESULTS AND CONCLUSION}

The results obtained, addressing the first research question manifest that almost all of the learners in three different levels had a strong positive preference toward error correction and the students favored to receive constant error correction rather than the selective one. As for peer correction in group works a total number of $86.7 \%$ of elementary students , $60 \%$ of intermediate students , and $43.4 \%$ of advanced level students agreed and strongly agreed .( shown in Tables 1,2 , $3)$.

TABLE 1:

ELEMENTARY STUDENTS' PREFERENCES TOWARD ERROR CORRECTION (KATAYAMA, 2007)

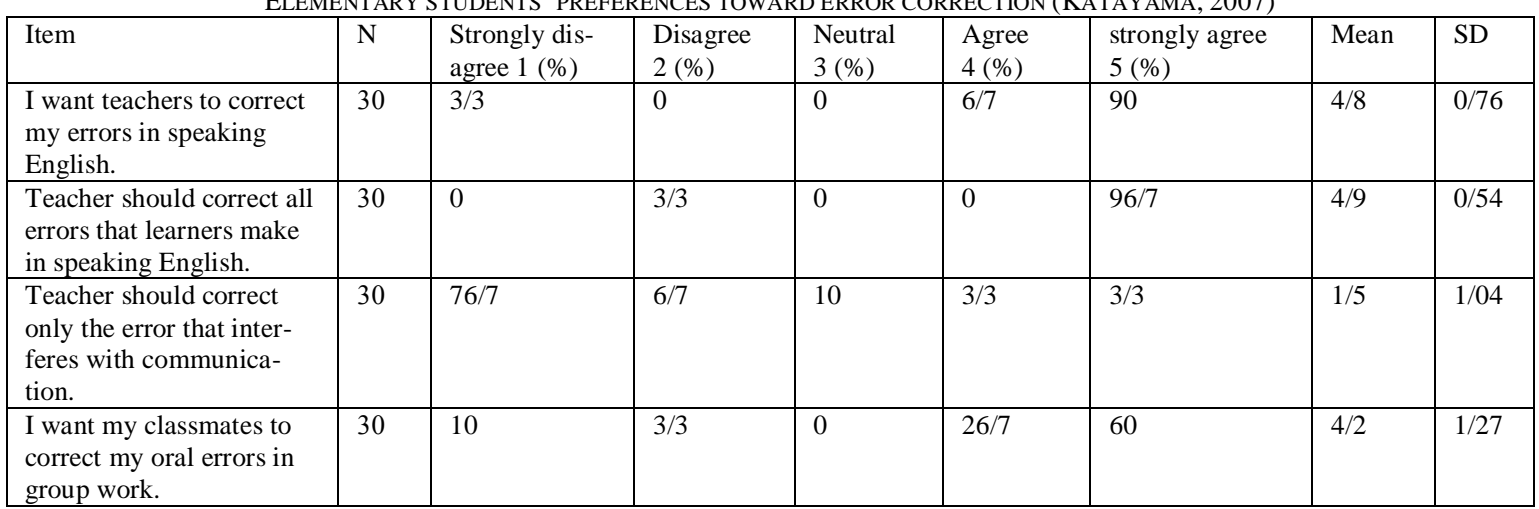

TABLE 2:

INTERMEDIATE STUDENTS’ PREFERENCES TOWARD ERROR CORRECTION (KATAYAMA, 2007)

\begin{tabular}{|c|c|c|c|c|c|c|c|c|}
\hline Item & $\mathrm{N}$ & $\begin{array}{l}\text { Strongly disagree } \\
1(\%)\end{array}$ & $\begin{array}{l}\text { disagree } \\
2(\%)\end{array}$ & $\begin{array}{l}\text { Neutral } \\
3(\%) \\
\end{array}$ & $\begin{array}{l}\text { agree } \\
4(\%)\end{array}$ & $\begin{array}{l}\text { strongly agree } \\
5(\%)\end{array}$ & Mean & SD \\
\hline $\begin{array}{l}\text { I want teachers to cor- } \\
\text { rect my errors in speak- } \\
\text { ing English. }\end{array}$ & 30 & 0 & $3 / 3$ & 0 & $16 / 7$ & 80 & $4 / 7$ & $0 / 63$ \\
\hline $\begin{array}{l}\text { Teacher should correct } \\
\text { all errors that learners } \\
\text { make in speaking Eng- } \\
\text { lish. }\end{array}$ & 30 & 0 & $3 / 3$ & $3 / 3$ & $33 / 3$ & 60 & $4 / 5$ & $0 / 73$ \\
\hline $\begin{array}{l}\text { Teacher should correct } \\
\text { only the error that inter- } \\
\text { feres with communica- } \\
\text { tion. }\end{array}$ & 30 & 50 & $36 / 7$ & $3 / 3$ & $3 / 3$ & $6 / 7$ & $1 / 8$ & $1 / 12$ \\
\hline $\begin{array}{l}\text { I want my classmates to } \\
\text { correct my oral errors } \\
\text { in group work. }\end{array}$ & 30 & $13 / 3$ & 10 & $16 / 7$ & $26 / 7$ & $33 / 3$ & $3 / 5$ & $1 / 40$ \\
\hline
\end{tabular}

TABLE 3:

ADVANCED STUDENTS' PREFERENCES TOWARD ERROR CORRECTION (KATAYAMA, 2007)

\begin{tabular}{|c|c|c|c|c|c|c|c|c|}
\hline Item & $\mathrm{N}$ & $\begin{array}{l}\text { Strongly disagree } \\
1(\%)\end{array}$ & $\begin{array}{l}\text { disagree } \\
2(\%)\end{array}$ & $\begin{array}{l}\text { Neutral } \\
3(\%)\end{array}$ & $\begin{array}{l}\text { agree } \\
4(\%)\end{array}$ & $\begin{array}{l}\text { strongly agree } \\
5(\%)\end{array}$ & Mean & SD \\
\hline $\begin{array}{l}\text { I want teachers to } \\
\text { correct my errors in } \\
\text { speaking English. }\end{array}$ & 30 & 0 & 0 & 0 & 30 & 70 & $4 / 7$ & $0 / 46$ \\
\hline $\begin{array}{l}\text { Teacher should cor- } \\
\text { rect all errors that } \\
\text { learners make in } \\
\text { speaking English. }\end{array}$ & 30 & 0 & $6 / 7$ & $16 / 7$ & 20 & $56 / 7$ & $4 / 2$ & $0 / 98$ \\
\hline $\begin{array}{l}\text { Teacher should cor- } \\
\text { rect only the errors } \\
\text { that interfere with } \\
\text { communication. }\end{array}$ & 30 & 20 & 40 & 20 & $13 / 3$ & $6 / 7$ & $2 / 4$ & $1 / 16$ \\
\hline $\begin{array}{l}\text { I want my classmates } \\
\text { to correct my oral } \\
\text { errors in group work. }\end{array}$ & 30 & 10 & 20 & $26 / 7$ & $26 / 7$ & $16 / 7$ & $3 / 2$ & $1 / 24$ \\
\hline
\end{tabular}


Consequently, the lower level students favored peer correction in group works more than the higher level ones. Considering students preferences toward peer correction, we reach to a point that there are some variables such as age differences, self-confidence, personality style, maturation development, and ... that indicated such differences between lower level and higher level students preferences toward peer correction in group works.

As for the types of errors students wanted to have corrected (second research question), the majority of the students in the three different levels expressed their preference in grammatical and vocabulary error correction over the other types (Shown in Tables 4, 5, 6.).

TABLE 4:

TYPES OF ERRORS ELEMENTARY STUDENTS WANTED TO HAVE CORRECTED (KATAYAMA, 2007)

\begin{tabular}{|l|l|l|l|l|l|l|l|l|}
\hline Item & $\mathrm{N}$ & $\begin{array}{l}\text { never } \\
1(\%)\end{array}$ & $\begin{array}{l}\text { often } \\
2(\%)\end{array}$ & $\begin{array}{l}\text { neutral } \\
3(\%)\end{array}$ & $\begin{array}{l}\text { sometimes } \\
4(\%)\end{array}$ & $\begin{array}{l}\text { always } \\
5(\%)\end{array}$ & Mean & SD \\
\hline Grammar & 30 & 0 & 0 & 0 & $6 / 7$ & $93 / 3$ & $4 / 9$ & $0 / 25$ \\
\hline Phonology & 30 & 0 & $6 / 7$ & 0 & 10 & $83 / 3$ & $4 / 7$ & $0 / 79$ \\
\hline Vocabulary & 30 & 0 & 0 & $3 / 3$ & $13 / 3$ & $83 / 3$ & $4 / 8$ & $0 / 48$ \\
\hline Pragmatics & 30 & 0 & $3 / 3$ & $6 / 7$ & $6 / 7$ & $83 / 3$ & $4 / 7$ & $0 / 74$ \\
\hline Discourse & 30 & $13 / 3$ & $3 / 3$ & $6 / 7$ & $16 / 7$ & 60 & 4 & $1 / 43$ \\
\hline
\end{tabular}

TABLE 5:

TYPES OF ERRORS INTERMEDIATE STUDENTS WANTED TO HAVE CORRECTED (KATAYAMA, 2007)

\begin{tabular}{|l|l|l|l|l|l|l|l|l|}
\hline Item & $\mathrm{N}$ & $\begin{array}{l}\text { never } \\
1(\%)\end{array}$ & $\begin{array}{l}\text { often } \\
2(\%)\end{array}$ & $\begin{array}{l}\text { neutral } \\
3(\%)\end{array}$ & $\begin{array}{l}\text { sometimes } \\
4(\%)\end{array}$ & $\begin{array}{l}\text { always } \\
5(\%)\end{array}$ & Mean & SD \\
\hline Grammar & 30 & 0 & $3 / 3$ & 0 & 10 & $86 / 7$ & $4 / 8$ & $0 / 61$ \\
\hline Phonology & 30 & 0 & $6 / 7$ & 10 & 20 & $63 / 3$ & $4 / 4$ & $0 / 93$ \\
\hline Vocabulary & 30 & 0 & $6 / 7$ & $3 / 3$ & 20 & 70 & $4 / 5$ & $0 / 86$ \\
\hline Pragmatics & 30 & $6 / 7$ & 0 & $6 / 7$ & 30 & $56 / 7$ & $4 / 3$ & $1 / 08$ \\
\hline Discourse & 30 & 0 & $13 / 3$ & $13 / 3$ & 40 & $33 / 3$ & $3 / 9$ & $1 / 01$ \\
\hline
\end{tabular}

TABLE 6:

TYPES OF ERRORS ADVANCED STUDENTS WANTED TO HAVE CORRECTED (KATAYAMA, 2007)

\begin{tabular}{|l|l|l|l|l|l|l|l|l|}
\hline Item & $\mathrm{N}$ & $\begin{array}{l}\text { never } \\
1(\%)\end{array}$ & $\begin{array}{l}\text { often } \\
2(\%)\end{array}$ & $\begin{array}{l}\text { neutral } \\
3(\%)\end{array}$ & $\begin{array}{l}\text { sometimes } \\
4(\%)\end{array}$ & $\begin{array}{l}\text { always } \\
5(\%)\end{array}$ & $\begin{array}{l}\text { Mean } \\
\text { SD }\end{array}$ \\
\hline Grammar & 30 & 0 & $3 / 3$ & 0 & $23 / 3$ & $73 / 3$ & $4 / 6$ & $0 / 66$ \\
\hline Phonology & 30 & 0 & $3 / 3$ & $3 / 3$ & $36 / 7$ & $56 / 7$ & $4 / 4$ & $0 / 73$ \\
\hline Vocabulary & 30 & 0 & 0 & $6 / 7$ & $26 / 7$ & $66 / 7$ & $4 / 6$ & $0 / 62$ \\
\hline Pragmatics & 30 & 0 & 0 & 10 & $36 / 7$ & $53 / 3$ & $4 / 4$ & $0 / 67$ \\
\hline Discourse & 30 & 0 & 0 & $13 / 3$ & 40 & $46 / 7$ & $4 / 3$ & $0 / 71$ \\
\hline
\end{tabular}

And finally the results obtained in the process of responding to the third research question demonstrated that, the technique of classroom error correction mostly preferred by the elementary students for both the grammatical and phonological errors was the one in which the teacher repeats the original question. As for the intermediate students most favored correction technique for both the grammatical and phonological errors was the one in which the teacher explains why the response is incorrect.

Lastly, the advanced students favored correction technique for grammatical errors was the one in which the teacher explains why the response is incorrect, and for phonological errors was the one in which the teacher gives student a hint which might enable student to notice the error and self-correct (Shown in Tables7, 8, 9, 10, 11, 12).

TABLE 7:

ELEMENTARY STUDENTS FAVORED CORRECTION TECHNIQUES FOR GRAMMATICAL ERRORS (KATAYAMA, 2007)

\begin{tabular}{|c|c|c|c|c|c|c|c|c|}
\hline Correction technique & $\mathrm{N}$ & $\begin{array}{l}\mathrm{Bad} \\
(\%)\end{array}$ & $\begin{array}{l}\text { no Good } \\
(\%)\end{array}$ & $\begin{array}{l}\text { Neutral } \\
(\%)\end{array}$ & $\begin{array}{l}\text { Good } \\
(\%)\end{array}$ & $\begin{array}{l}\text { Very good } \\
(\%)\end{array}$ & Mean & $\mathrm{SD}$ \\
\hline $\mathrm{T}$ repeats the original question. & 30 & 0 & $6 / 7$ & 0 & $13 / 3$ & 80 & $3 / 7$ & $0 / 58$ \\
\hline $\mathrm{T}$ asks $\mathrm{S}^{\prime}$ to repeat the utterance. & 30 & $3 / 3$ & 0 & $6 / 7$ & $13 / 3$ & $76 / 7$ & $3 / 5$ & $1 / 13$ \\
\hline $\begin{array}{l}\mathrm{T} \text { repeats } \mathrm{S}^{\prime} \text { utterance up to the error and waits } \\
\text { for self-correction. }\end{array}$ & 30 & 10 & 0 & $3 / 3$ & $16 / 7$ & 70 & $3 / 4$ & $1 / 13$ \\
\hline $\begin{array}{l}\text { T gives } S^{\prime} \text { a hint which might enable } S \text { to notice } \\
\text { the error and self-correct. }\end{array}$ & 30 & $6 / 7$ & 0 & $6 / 7$ & $13 / 3$ & $73 / 3$ & $3 / 4$ & $1 / 22$ \\
\hline $\begin{array}{l}\mathrm{T} \text { points out the error and provides the correct } \\
\text { response. }\end{array}$ & 30 & 10 & $3 / 3$ & $3 / 3$ & $6 / 7$ & $76 / 7$ & $3 / 4$ & $1 / 16$ \\
\hline $\begin{array}{l}\text { T indicates that an error occurred by nonverbal } \\
\text { behavior, such as gesture and facial expres- } \\
\text { sions. }\end{array}$ & 30 & $16 / 7$ & $3 / 3$ & 0 & 10 & 70 & $3 / 3$ & $1 / 15$ \\
\hline T explains why the response is incorrect. & 30 & $26 / 7$ & 0 & 0 & $6 / 7$ & $66 / 7$ & $3 / 1$ & $1 / 33$ \\
\hline $\begin{array}{l}\mathrm{T} \text { presents the correct response or part of the } \\
\text { response. }\end{array}$ & 30 & $16 / 7$ & 0 & 10 & $6 / 7$ & $66 / 7$ & 3 & $1 / 51$ \\
\hline $\mathrm{T}$ indicates the error. & 30 & $53 / 3$ & $3 / 3$ & 10 & 10 & $23 / 3$ & $1 / 8$ & $1 / 41$ \\
\hline T ignores $\mathrm{S}^{\prime}$ error. & 30 & $86 / 7$ & $6 / 7$ & 0 & $6 / 7$ & 0 & $3 / 8$ & $0 / 55$ \\
\hline
\end{tabular}


TABLE 8:

INTERMEDIATE STUDENTS FAVORED CORRECTION TECHNIQUES FOR GRAMMATICAL ERRORS (KATAYAMA, 2007)

\begin{tabular}{|c|c|c|c|c|c|c|c|c|}
\hline Correction technique & $\mathrm{N}$ & $\begin{array}{l}\mathrm{Bad} \\
(\%)\end{array}$ & $\begin{array}{l}\text { no Good } \\
(\%)\end{array}$ & $\begin{array}{l}\text { Neutral } \\
(\%)\end{array}$ & $\begin{array}{l}\text { Good } \\
(\%)\end{array}$ & $\begin{array}{l}\text { Very good } \\
(\%)\end{array}$ & Mean & $\mathrm{SD}$ \\
\hline T explains why the response is incorrect. & 30 & 0 & 0 & $6 / 7$ & $13 / 3$ & 80 & $3 / 6$ & $1 / 03$ \\
\hline $\begin{array}{l}\text { T gives } S^{\prime} \text { a hint which might enable } \mathrm{S} \text { to notice the } \\
\text { error and self-correct. }\end{array}$ & 30 & 0 & $3 / 3$ & $3 / 3$ & 40 & $53 / 3$ & $3 / 4$ & $0 / 85$ \\
\hline T asks $S^{\prime}$ to repeat the utterance. & 30 & $3 / 3$ & $6 / 7$ & $6 / 7$ & $36 / 7$ & $46 / 7$ & $3 / 1$ & $1 / 13$ \\
\hline $\begin{array}{l}\text { T repeats S' utterance up to the error and waits for } \\
\text { self-correction. }\end{array}$ & 30 & $3 / 3$ & 10 & $6 / 7$ & $26 / 7$ & $53 / 3$ & $3 / 1$ & $1 / 17$ \\
\hline $\begin{array}{l}\text { T points out the error and provides the correct re- } \\
\text { sponse. }\end{array}$ & 30 & $6 / 7$ & $13 / 3$ & $6 / 7$ & 10 & $63 / 3$ & $3 / 1$ & $1 / 28$ \\
\hline T repeats the original question. & 30 & 0 & 10 & $16 / 7$ & 30 & $43 / 3$ & $2 / 8$ & $1 / 44$ \\
\hline $\mathrm{T}$ indicates the error. & 30 & $6 / 7$ & $13 / 3$ & 10 & $43 / 3$ & $26 / 7$ & $2 / 7$ & $1 / 23$ \\
\hline $\begin{array}{l}\text { T presents the correct response or part of the re- } \\
\text { sponse. }\end{array}$ & 30 & $13 / 3$ & 10 & $13 / 3$ & $26 / 7$ & $36 / 7$ & $2 / 6$ & $1 / 45$ \\
\hline $\begin{array}{l}\text { T indicates that an error occurred by nonverbal } \\
\text { behavior, such as gesture and facial expressions. }\end{array}$ & 30 & $13 / 3$ & 10 & 20 & 20 & $36 / 7$ & $2 / 4$ & $1 / 58$ \\
\hline T ignores $\mathrm{S}^{\prime}$ error. & 30 & $76 / 7$ & $3 / 3$ & $3 / 3$ & $6 / 7$ & 10 & $3 / 4$ & $1 / 19$ \\
\hline
\end{tabular}

TABLE 9:

ADVANCED STUDENTS FAVORED CORRECTION TECHNIQUES FOR GRAMMATICAL ERRORS (KATAYAMA, 2007)

\begin{tabular}{|c|c|c|c|c|c|c|c|c|}
\hline Correction technique & $\mathrm{N}$ & $\begin{array}{l}\mathrm{Bad} \\
(\%)\end{array}$ & $\begin{array}{l}\text { no Good } \\
(\%)\end{array}$ & $\begin{array}{l}\text { Neutral } \\
(\%)\end{array}$ & $\begin{array}{l}\text { Good } \\
(\%)\end{array}$ & $\begin{array}{l}\text { Very good } \\
(\%)\end{array}$ & Mean & SD \\
\hline $\mathrm{T}$ explains why the response is incorrect. & 30 & $13 / 3$ & $3 / 3$ & $6 / 7$ & 20 & $56 / 7$ & 3 & $1 / 33$ \\
\hline $\begin{array}{l}\mathrm{T} \text { gives } \mathrm{S}^{\prime} \text { a hint which might enable } \mathrm{S} \text { to notice } \\
\text { the error and self-correct. }\end{array}$ & 30 & $3 / 3$ & $13 / 3$ & $6 / 7$ & $43 / 3$ & $33 / 3$ & $2 / 9$ & $1 / 11$ \\
\hline $\begin{array}{l}\text { T points out the error and provides the correct } \\
\text { response. }\end{array}$ & 30 & $6 / 7$ & $13 / 3$ & $6 / 7$ & $23 / 3$ & 50 & 3 & $1 / 24$ \\
\hline T asks $S^{\prime}$ to repeat the utterance. & 30 & 10 & $23 / 3$ & $3 / 3$ & $43 / 3$ & 20 & $2 / 6$ & $1 / 02$ \\
\hline $\mathrm{T}$ repeats the original question. & 30 & $3 / 3$ & 20 & $16 / 7$ & $43 / 3$ & $16 / 7$ & $2 / 4$ & $1 / 30$ \\
\hline $\begin{array}{l}\mathrm{T} \text { presents the correct response or part of the } \\
\text { response. }\end{array}$ & 30 & $3 / 3$ & 30 & $13 / 3$ & $23 / 3$ & 30 & $2 / 5$ & $1 / 33$ \\
\hline $\begin{array}{l}\text { T repeats } S^{\prime} \text { utterance up to the error and waits for } \\
\text { self-correction. }\end{array}$ & 30 & $3 / 3$ & 20 & $23 / 3$ & 30 & $23 / 3$ & $2 / 2$ & $1 / 48$ \\
\hline $\mathrm{T}$ indicates the error. & 30 & $26 / 7$ & $6 / 7$ & $26 / 7$ & $33 / 3$ & $6 / 7$ & $1 / 6$ & $1 / 37$ \\
\hline $\begin{array}{l}\text { T indicates that an error occurred by nonverbal } \\
\text { behavior, such as gesture and facial expressions. }\end{array}$ & 30 & $16 / 7$ & 20 & 30 & $23 / 3$ & 10 & $1 / 6$ & $1 / 39$ \\
\hline T ignores $S^{\prime}$ error. & 30 & $96 / 7$ & 0 & $3 / 3$ & 0 & 0 & $3 / 8$ & $0 / 73$ \\
\hline
\end{tabular}

TABLE 10:

ELEMENTARY STUDENTS FAVORED CORRECTION TECHNIQUES FOR PHONOLOGICAL ERRORS (KATAYAMA, 2007)

\begin{tabular}{|c|c|c|c|c|c|c|c|c|}
\hline Correction technique & $\mathrm{N}$ & $\begin{array}{l}\mathrm{Bad} \\
(\%)\end{array}$ & $\begin{array}{l}\text { no Good } \\
(\%)\end{array}$ & $\begin{array}{l}\text { Neutral } \\
(\%)\end{array}$ & $\begin{array}{l}\text { Good } \\
(\%)\end{array}$ & $\begin{array}{l}\text { Very good } \\
(\%)\end{array}$ & Mean & SD \\
\hline $\mathrm{T}$ repeats the original question. & 30 & 0 & $3 / 3$ & $3 / 3$ & $16 / 7$ & $76 / 7$ & $3 / 6$ & $0 / 85$ \\
\hline$T$ asks $S^{\prime}$ to repeat the utterance. & 30 & $3 / 3$ & 0 & $6 / 7$ & 10 & 80 & $3 / 5$ & $1 / 13$ \\
\hline $\begin{array}{l}\text { T repeats } S^{\prime} \text { utterance up to the error and waits for } \\
\text { self-correction. }\end{array}$ & 30 & 10 & 0 & 0 & 20 & 70 & $3 / 5$ & $0 / 93$ \\
\hline $\begin{array}{l}\text { T points out the error and provides the correct re- } \\
\text { sponse. }\end{array}$ & 30 & 10 & $3 / 3$ & 0 & 10 & $76 / 7$ & $3 / 5$ & $0 / 97$ \\
\hline $\begin{array}{l}\text { T gives } S^{\prime} \text { a hint which might enable } \mathrm{S} \text { to notice the } \\
\text { error and self-correct. }\end{array}$ & 30 & 10 & 0 & $3 / 3$ & 10 & $76 / 7$ & $3 / 4$ & $1 / 13$ \\
\hline $\begin{array}{l}\mathrm{T} \text { indicates that an error occurred by nonverbal } \\
\text { behavior, such as gesture and facial expressions. }\end{array}$ & 30 & $16 / 7$ & $3 / 3$ & $3 / 3$ & 10 & $66 / 7$ & $3 / 2$ & $1 / 29$ \\
\hline $\begin{array}{l}\text { T presents the correct response or part of the re- } \\
\text { sponse. }\end{array}$ & 30 & $16 / 7$ & $6 / 7$ & $6 / 7$ & $6 / 7$ & $63 / 3$ & 3 & $1 / 42$ \\
\hline $\mathrm{T}$ explains why the response is incorrect. & 30 & $26 / 7$ & 0 & $3 / 3$ & $6 / 7$ & $63 / 3$ & 3 & $1 / 43$ \\
\hline $\mathrm{T}$ indicates the error. & 30 & $53 / 3$ & 0 & 10 & $6 / 7$ & 30 & $1 / 9$ & $1 / 50$ \\
\hline T ignores S' error. & 30 & $93 / 3$ & $3 / 3$ & 0 & 0 & $3 / 3$ & $3 / 8$ & $0 / 57$ \\
\hline
\end{tabular}


TABLE 11:

INTERMEDIATE STUDENTS FAVORED CORRECTION TECHNIQUES FOR PHONOLOGICAL ERRORS (KATAYAMA, 2007)

\begin{tabular}{|c|c|c|c|c|c|c|c|c|}
\hline Correction technique & $\mathrm{N}$ & $\begin{array}{l}\mathrm{Bad} \\
(\%)\end{array}$ & $\begin{array}{l}\text { no Good } \\
(\%)\end{array}$ & $\begin{array}{l}\text { Neutral } \\
(\%)\end{array}$ & $\begin{array}{l}\text { Good } \\
(\%)\end{array}$ & $\begin{array}{l}\text { Very good } \\
(\%)\end{array}$ & Mean & SD \\
\hline T explains why the response is incorrect. & 30 & 0 & 0 & 10 & $6 / 7$ & $83 / 3$ & $3 / 5$ & $1 / 22$ \\
\hline T asks $S^{\prime}$ to repeat the utterance. & 30 & $3 / 3$ & $6 / 7$ & $3 / 3$ & 40 & $46 / 7$ & $3 / 2$ & $0 / 97$ \\
\hline $\begin{array}{l}\mathrm{T} \text { gives } \mathrm{S}^{\prime} \text { a hint which might enable } \mathrm{S} \text { to notice the } \\
\text { error and self-correct. }\end{array}$ & 30 & 0 & $3 / 3$ & $13 / 3$ & $36 / 7$ & $46 / 7$ & 3 & $1 / 32$ \\
\hline $\mathrm{T}$ repeats the original question. & 30 & 0 & 10 & $16 / 7$ & $26 / 7$ & $46 / 7$ & $2 / 8$ & $1 / 45$ \\
\hline $\begin{array}{l}\text { T points out the error and provides the correct re- } \\
\text { sponse. }\end{array}$ & 30 & $6 / 7$ & $6 / 7$ & $16 / 7$ & $13 / 3$ & $56 / 7$ & $2 / 8$ & $1 / 56$ \\
\hline $\begin{array}{l}\text { T repeats } S^{\prime} \text { utterance up to the error and waits for } \\
\text { self-correction. }\end{array}$ & 30 & $3 / 3$ & 10 & $16 / 7$ & 30 & 40 & $2 / 7$ & $1 / 46$ \\
\hline $\begin{array}{l}\text { T presents the correct response or part of the re- } \\
\text { sponse. }\end{array}$ & 30 & 10 & 10 & $13 / 3$ & 20 & $46 / 7$ & $2 / 7$ & $1 / 47$ \\
\hline $\mathrm{T}$ indicates the error. & 30 & $6 / 7$ & $13 / 3$ & $13 / 3$ & 40 & $26 / 7$ & $2 / 6$ & $1 / 32$ \\
\hline $\begin{array}{l}\text { T indicates that an error occurred by nonverbal beha- } \\
\text { vior, such as gesture and facial expressions. }\end{array}$ & 30 & $16 / 7$ & $6 / 7$ & 20 & $13 / 3$ & $43 / 3$ & $2 / 4$ & $651 /$ \\
\hline T ignores $\mathrm{S}^{\prime}$ error. & 30 & $76 / 7$ & $3 / 3$ & 10 & 0 & 10 & $3 / 2$ & $1 / 43$ \\
\hline
\end{tabular}

TABLE 12:

ADVANCED STUDENTS FAVORED CORRECTION TECHNIQUES FOR PHONOLOGICAL ERRORS (KATAYAMA, 2007)

\begin{tabular}{|c|c|c|c|c|c|c|c|c|}
\hline Correction technique & $\mathrm{N}$ & $\begin{array}{l}\mathrm{Bad} \\
(\%)\end{array}$ & $\begin{array}{l}\text { no Good } \\
(\%)\end{array}$ & $\begin{array}{l}\text { Neutral } \\
(\%)\end{array}$ & $\begin{array}{l}\text { Good } \\
(\%)\end{array}$ & $\begin{array}{l}\text { Very good } \\
(\%)\end{array}$ & Mean & $\mathrm{SD}$ \\
\hline $\begin{array}{l}\mathrm{T} \text { gives } \mathrm{S}^{\prime} \text { a hint which might enable } \mathrm{S} \text { to notice } \\
\text { the error and self-correct. }\end{array}$ & 30 & $3 / 3$ & $16 / 7$ & $3 / 3$ & $46 / 7$ & 30 & $2 / 9$ & $0 / 96$ \\
\hline $\begin{array}{l}\text { T points out the error and provides the correct } \\
\text { response. }\end{array}$ & 30 & $6 / 7$ & $13 / 3$ & 10 & $16 / 7$ & $53 / 3$ & $2 / 9$ & $1 / 37$ \\
\hline T explains why the response is incorrect. & 30 & $13 / 3$ & 10 & 10 & 20 & $46 / 7$ & $2 / 8$ & $1 / 42$ \\
\hline T asks $S^{\prime}$ to repeat the utterance. & 30 & $13 / 3$ & 20 & $6 / 7$ & 40 & 20 & $2 / 5$ & $1 / 16$ \\
\hline $\mathrm{T}$ repeats the original question. & 30 & 10 & $23 / 3$ & 10 & 1343 & $13 / 3$ & $2 / 4$ & $1 / 16$ \\
\hline $\begin{array}{l}\text { T presents the correct response or part of the } \\
\text { response. }\end{array}$ & 30 & $3 / 3$ & 30 & $13 / 3$ & $26 / 7$ & $26 / 7$ & $2 / 5$ & $1 / 30$ \\
\hline $\begin{array}{l}\text { T repeats S' utterance up to the error and waits for } \\
\text { self-correction. }\end{array}$ & 30 & $6 / 7$ & $16 / 7$ & $23 / 3$ & 30 & $23 / 3$ & $2 / 2$ & $1 / 50$ \\
\hline $\begin{array}{l}\mathrm{T} \text { indicates that an error occurred by nonverbal } \\
\text { behavior, such as gesture and facial expressions. }\end{array}$ & 30 & $16 / 7$ & $16 / 7$ & $26 / 7$ & 30 & 10 & $1 / 8$ & $1 / 39$ \\
\hline $\mathrm{T}$ indicates the error. & 30 & $26 / 7$ & $6 / 7$ & $26 / 7$ & $36 / 7$ & $3 / 3$ & $1 / 6$ & $1 / 32$ \\
\hline T ignores S' error. & 30 & $76 / 7$ & $6 / 7$ & $13 / 3$ & 0 & $3 / 3$ & $3 / 3$ & $1 / 44$ \\
\hline
\end{tabular}

Of course these results are based on the percentage of the respondents who gave scores of 4 and 5 in the last section of the questionnaire. Over all the current results emphasize the importance of teachers being familiar with a variety of oral correction strategies so as to cater for students' individual factors such as learning styles, personalities, preferences, attitudes, and aptitudes. Moreover, teachers should be able to create a classroom environment which is unthreatening and conducive to effective learning. Further, students opinions should be taken into account and their preferences should be taken seriously because error correction is provided for their sake, and thus they should have a say in who, when, how, and what of their error correction. Additionally, the teachers should take the opportunity to find out their students opinions and preferences toward the pedagogical practice.

\section{Pedagogical IMPLiCATIONS AND APPLiCATions}

The results obtained in the current study may provide useful insights regarding the Iranian EFL learner's preferences toward classroom oral error correction with a main focus on their proficiency level. The results of the research also give important hints about the Iranian EFL learner's preferences on the correction of errors regarding not only grammar and vocabulary usage but also peer-correction, teacher-feedback techniques and self-correction. Thus, instructors and teachers at institutions or schools may focus on the preferences of the learners regarding their oral errors and the learners may also become more conscious about error correction in general. Firstly, the Iranian EFL learners do not prefer direct error correction especially in elementary and intermediate levels for grammatical error correction. Thus, the teachers should be sensitive about not providing direct feedback to them. In addition, advanced learners tend to prefer direct error correction more than other levels. The Iranian elementary, intermediate, and advanced level students are sensitive about the correction of grammar and vocabulary and phonological errors more than the other errors. For this reason, the teachers should provide feedback about their oral grammatical, lexicon, and pronunciation errors without hurting their feelings. Secondly, the elementary $(86 / 7 \%)$ and intermediate $(60 \%)$ students prefer peer-correction in group works because they feel more comfortable with their friends and by peer-correction they feel that they could enhance their selfconfidence. Thus, the teachers should tolerate peer correction. However, the learners expect teacher confirmation after peer-correction. All these may suggest that all level learners are not ready to be corrected by their peers as they are still teacher-dependent. Elementary learners are more sensitive and conscious about peer-correction and the intermediate and advanced level learners should be more trained and motivated for peer-correction. Thirdly, the Iranian learners pre- 
fer constant error correction over the selective one. When circumstances do not allow the teachers to modify their classroom practices, they should explain their rationale to their students. Such explanations could at least partially minimize conflict in preferences between teachers and students. Both the learners and the teachers should have more opportunities to learn more about the correction of oral errors. Conferences, workshops and seminars should be organized so that teachers and students can be more conscious. Fourthly, the EFL teachers should be trained for various correction techniques regarding their students' level of proficiency, age, preference. Fifthly, the EFL learners should be motivated and trained to correct their oral errors by themselves. Thus the EFL teachers need to be trained for various self-correction strategies. Sixthly, it can be suggested that material developers, while writing Iranian school text books for different grades, can benefit from the findings of this study. They can develop the text books in a way that more attention should be paid to communication rather than strict grammar and lexicon. This indicates a significant change in our educational system and removing the entrance examinations of universities. Therefore without only enhancing the students' grammar and vocabulary knowledge at schools, we can improve their abilities in communication, allowing them to be able to be good speakers in daily-life conversations. And lastly, the material writers can focus on more group working activities, consequently, the teachers should develop peer-correction in group works.

\section{SUGGESTIONS FOR FURTHER RESEARCH}

Based on the limitations of the current study, further studies may be carried out with more participants including both male and female learners in different EFL contexts. It is recommended to extend such studies by involving EFL learners involved in schools or universities to see whether the same or different findings are resulted. Attending to this suggestion and conducting similar studies may make it easier to generalize the findings to larger contexts. In addition to using a single questionnaire for the learners, likewise a questionnaire may be handed out to the Iranian EFL teachers in order to elicit information on their preferences toward the oral error correction. In addition, teacher's preferences and student's preferences may be compared with each other to analyze the similarities and differences of their viewpoints. Even the learners and the teachers may be interviewed and classroom observation can be carried out. Classroom observations and interviews may broaden the perspectives of the research. Another recommendation is research that addresses the reasons for the student's preferences for particular correction techniques as well as preferences for classroom error corrections of different types of errors. Another recommendation is investigating cross-cultural differences to find out whether learner's perceptions differ across cultures. Lastly, in a likewise study we can find out about the time of error correction or in other words whether learners prefer immediate or delayed correction of their errors.

\section{REFERENCES}

[1] Brown, H.D. (2009). Teaching by principles: An interactive approach to language pedagogy. White plains, NY: Pearson Education.

[2] Horwitz, E.K. (1988). The beliefs about language learning of beginning university foreign language students. The Modern Language Journal. vol. 72 (3), pp. 125-132.

[3] Katayama, A. (2006). Perceptions of JFL students toward correction of oral errors. In K. Bradford-watts, C. Ikeguchi, \& M. Swanson (Eds.) JALT 2005 Conference Proceedings. Tokio: JALT.

[4] Katayama, A. (2007). Japanese EFL Student's Preferences toward Correction of Classroom Oral Errors, Asian EFL Journal, vol. 9. No. 4: Conference Proceedings.

[5] Nunan, D. (1987). Communicative language teaching: The learner's view. In K.D. Bikarm (Ed.), Communication and learning in classroom community, pp. 176-190, Singapore: SEAMEO Regional Language Centre.

[6] Schulz, R.A. (1996). Focus on form in the Foreign language classroom: Student's and teacher's views on error correction and the role of grammar. Foreign Language Annals, 29(3), pp.17-21.

[7] Schulz, R.A.(2001). Cultural differences in student and teacher perceptions concerning the role of grammar instruction and corrective feedback: USA-Columbia. The Modern Language Journal, 85(2), pp. 56-75.

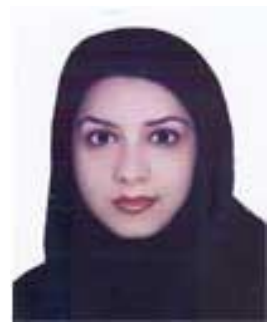

Rana Kazemi. Born in Iran, Tabriz on 1979-08-02

BA in English Language and Literature from Islamic Azad University-Tabriz Branch, Tabriz, Iran.

MA in English Language Teaching from Islamic Azad University-Ahar Branch, Ahar, Iran.

She owns an English Institute named Pardisan in Tabriz, Iran. She works as the manager and teaches English. 


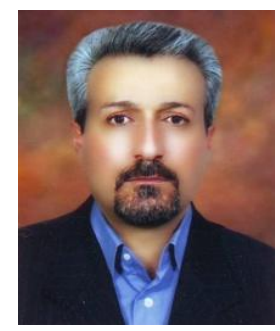

Seyed Mahdi Araghi, born in Iran, Marand on 1965-10-01

BA in English Language and Literature from Islamic Azad University-Tabriz Branch, Tabriz, Iran. (1993) MA in ELT from Islamic Azad University-Tabriz Branch, Tabriz, Iran. (1997)

Ph.D. in ELT from Panjab University, Chandigarh, India. (2005)

He has been teaching in different universities in Iran for almost 20 years, previously as a lecturer and now as an assistant professor in Payame Noor University, Tabriz. He has published and presented some papers in different journals and conferences and also has written and translated a few books. His main interests are in the field of psycholinguistics and EFL/ESL.

Hanieh Davatgari, Born in Iran, Tabriz on 1981-07-13

BA in ELT from Islamic Azad University-Tabriz Branch, Tabriz, Iran. (2003)

MA in ELT from Shahid Madany University, Tabriz, Iran. (2006)

Ph.D. in ELT from Islamic Azad University-Tabriz Branch, Tabriz, Iran. (2013)

She is a lecturer in TEFL at the Department of English Language, Ahar Branch, Islamic Azad University. She obtained her PhD degree from Islamic Azad University/ Tabriz Branch. Her main interests are in the area of Task-based language Teaching, Language testing and their interface with the issues in English Language Teaching. She has published and presented some papers in journals and conferences. 